\title{
Agroforestry potential of Ricinodendron heudelotii (Baill.) Pierre ex Pax in Nigeria
}

\author{
Alfred Ossai Onefeli, \\ Adejoke Olukemi Akinyele, \\ Hezekiah Tunde Fatoba \\ Vytautas Magnus \\ University Agriculture Academy, \\ 11 Studentu Street, \\ 53361 Kaunas District, Lithuania \\ Email: ftaxonomist@gmail.com; \\ alfred.ossai.onefeli@vdu.lt
}

With the current geometric increase in Nigerian population and the depleted soil nutrients vis-à-vis decreased agricultural outputs. It becomes pertinent to identify important indigenous multiple agroforestry trees that would be compatible with food crops on the same piece of land for multiple outputs. This study aimed at determining the agroforestry potential of Ricinodendron heudelotii with focus on the ex-situ growth rate of the tree, compatibility with maize as a test crop, coppicing ability and its impact on soil nutrients.

The experiment was sited at the Teaching and Research Farm, University of Ibadan, Nigeria, utilizing two alley widths $(3$ and $6 \mathrm{~m})$ and control $(15 \times 10 \mathrm{~m})$. Maize plants were intercropped with trees at two different seasons (dry and rain), six months after tree planting, but only the rain season maize survived for further analysis. Data were collected on the height, collar diameter and number of leaves of the trees and maize. Soil analysis was carried out before and after the experiment. The data were subjected to descriptive statistics, ANOVA, $t$-test, Kruskal Wallis and Mann-Whitney U Test.

The results showed that the effect of alley treatment was significant $(p<0.05)$ on tree and maize growth with the $6 \mathrm{~m}$ alley having the highest values. The effect of planting distance was not significant on maize growth. The alley agroforestry practice significantly $(p<0.05)$ improved the soil properties of the site, especially for $\mathrm{pH}$, available phosphorus, magnesium and natrium.

The findings from this study indicated that it is possible to incorporate maize into the alley of Ricinodendron heudelotii for multiple productions.

Keywords: agroforestry, alley cropping, Ricinodendron heudelotii, maize, soil nutrients

\section{INTRODUCTION}

Ricinodendron heudelotii (Baill.) Pierre ex Pax is a tree species commonly known as African WoodOil Nut Tree, which has been widely useful for human existence. Virtually all its parts are utilized for one purpose or the other (Tiki-Manga et al., 2000; Plenderleith, 2004; Udo, Epidi, 2009; Facheux et al., 2012; Nzali et al., 2016; Ndumbe et al., 2018; Zerotabou, 2019). According to Tiki-Manga et al. (2000), the three most significant uses of $R$. heu- delotii are food, medicinal and cultural purposes. Ngo-Mpeck et al. (2003) asserted that the nut of the species is one of the major flavouring agents that the rural dwellers cannot do without in their local dishes. This is due to its contribution to their balanced diet. It has equally been established that oil generated from $R$. heudelotii seeds is good to produce paints for surface coating (Yirankinyuki et al., 2018). Its ethnomedicinal importance cannot be overemphasized. Several diseases have been cured using decoction prepared from different 
parts of the plant. For instance, extracts made from the leaves are used for the treatment of fever, malaria, anaemia, stomach pain, headache, toothache and to provide easy child delivery (Tchoundjeu, Atangana, 2006). Socioculturally, the seeds are used by Ibos in Nigeria for the 'Okwe' game, while the wood is traditionally used to produce drums (Fondoun et al., 1999; Tchoundjeu, Atangana, 2006; Fuashi et al., 2011; FAO, 2012; Cosyns et al., 2014). There are shreds of evidence that $R$. heudelotii stands are purposively speared on the plots when forests are newly cleared for agricultural purposes in many parts of Kenya and Nigeria (Tengnas, 1994; Oke, Odebiyi, 2007). This is because the leaves are variously utilized as good quality fodder for sheep and goats during the dry season (Anigbogu, 1996; Nzali et al., 2016). Despite these mentioned benefits derived from $R$. heudelotii, its agroforestry potential is yet to be studied.

According to Tengnas (1994), a good agroforestry tree is characterised by a fast growth rate, ability to coppice quickly after pollarding, ability to improve soil nutrients and compatibility with crops on the field. Since growth rate is very significant as far as the quality of agroforestry tree component is concerned (Barrios et al., 2019), determining the indigenous tree species with a considerable fast growth rate is still a problem in the Nigeria agroforestry system. This culminates from the fact that most indigenous tree growth studies end up in the nursery, and as such, the early growth on the field, where little or no external resources are supplied, is not known (Verinumbe, 2017). This has undoubtedly limited the expanded use of indigenous species for afforestation, reforestation and agroforestry purposes.

Soils of tropical regions, such as in Nigeria, where there are problems of degradation of habitat and loss of biological diversity following shifting cultivation and logging practices, are nutrient-deficient (Mukul, Herbohn, 2016). The poor-nutrient soils have hitherto aggravated the low yield obtained in many arable crops produce like maize, which are cultivated solely in an exposed field without a complementary impact of the tree (Amujoyegbe, Elemo, 2011). Consequently, rural communities are still battling with the problem of food insecurity. Therefore, in the face of the decreased agricultural production capacity triggered by land degradation in Nigeria, incorporating $R$. heudelotii into agricultural cropland such as maize would be one of the means for food security to the local farmers as well as the entire populace in the country. If well designed and adopted by the local farmers, it is capable of diversifying the production output, which would have been single-crop-output under agricultural management practice alone. This study therefore aimed at determining the agroforestry potential of $R$. heudelotii to provide the information required for the diversification of agriculture and forest productivity.

\section{RESEARCH METHODS AND CONDITIONS}

This study was sited at the Teaching and Research Farm, University of Ibadan, Nigeria, and it lasted for the period of 15 months (from April 2017 to July 2018). The University of Ibadan is located on latitudes $7^{\circ} 46^{\prime} 20.27^{\prime \prime} \mathrm{N}$ and $7^{\circ} 43^{\prime} 28.33^{\prime \prime} \mathrm{N}$, longitude $3^{\circ} 88^{\prime} 27.93^{\prime \prime} \mathrm{E}$ and $3^{\circ} 90^{\prime} 78^{\prime \prime} \mathrm{E}$, on the edge of the derived savannah ecosystem. It has a humid tropical wet and dry climate and a relatively cool environment with an average rainfall of $1420.06 \mathrm{~mm}$ and relative humidity of $74.55 \%$. The agroforestry practice used for this study is alley cropping and the method of Keerthisena and Gunawardana (1996) was adopted with little modifications. Alley cropping involves the simultaneous cultivation of the arable crop in between the rows (alleys) of trees. Maize was utilized as the test crop because it is one of the most important sources of food for human and animal nutrition and raw materials for industrial processing (Krasauskas, 2018).

Due to fair uniformity observed on the topography of the plot used, the study utilized a completely randomized design with three replications. Before and after the experiment, soil samples were collected systematically from the experimental plot to a depth of $15 \mathrm{~cm}$ using a soil auger and air-dried for onward analysis of organic carbon, total nitrogen, $\mathrm{pH}$, available phosphorus, $\mathrm{Fe}^{3+}$ and exchangeable cations $\left(\mathrm{K}^{+}, \mathrm{Ca}^{2+}, \mathrm{Na}^{+}, \mathrm{Mg}^{2+}\right)$ (Falade, Bada, 2009; Akinbisoye et al., 2014). A total number of $120 \mathrm{R}$. heudelotii seedlings raised at the Nursery Unit of the Department of Forest Production and Products, University of Ibadan, were used for this study. The experiment involved two alley widths of 3 and $6 \mathrm{~m}$ planted at $1 \mathrm{~m}$ spacing with control $(15 \times 10 \mathrm{~m})$ having 
no tree. The total dimension of the alley plot was $30 \times 10 \mathrm{~m}$ containing a total of 7 rows of trees. Trees were allowed to stabilize for six months before the incorporation of maize as a test plant. During this period, silvicultural practices such as weeding and beating-up were carried out using a cutlass and a hoe. Maize seeds were sown in the alleys of $R$. heudelotii and in the control plot at a row espacement of $60 \mathrm{~cm}$. Each of the 6 and $3 \mathrm{~m}$ alleys contained 7 and 2 rows of maize, respectively (Reynolds et al., 2007). Four maize distances to the trees were used according to Keerthisena, Gunawardana (1996). These include $120,180,240$ and $300 \mathrm{~cm}$. The sowing of maize was carried out both in the dry and the wet season, but the dry season maize failed to survive due to the problem of pests such as Thryonomys swinderianus, which burrowed into the soil and consumed most of the seeds before germination. The height, collar diameter and number of leaves of the survived during the wet season maize plants were taken every two weeks for the period of three months while the height, collar diameter and number of leaves of the trees were determined every month using a meter tape, Vernier calliper and visual counting for twelve months to document the early growth of the tree species on-site. Pollarding of the trees was done once at the twelfth month of tree planting to determine the coppicing ability of the trees, while the leaves were used as mulch on the plot. The coppices lengths and number of leaves of the pollarded trees were assessed for three months before the termination of the experiment.

The data were analysed for descriptive statistics, analysis of variance (ANOVA), $t$-test, Kruskal Wallis and Mann-Whitney $U$ test using Statistica
Version 7, IBM SPSS version 20 and Microsoft Excel 2016. Mann-Whitney U was used to compare the significant difference in the number of $R$. heudelotii leaves produced from the two alley widths, while Kruskal Wallis was used to determining the effect of distance to the tree on the number of leaves produced by the maize crop. $T$-test was used to analyse the significant difference in the height and collar diameter of trees between the two alley widths. ANOVA was used to determine the significant effect of distance to the tree on the maize collar diameter and height.

\section{RESULTS AND DISCUSSION}

At the end of the one-year growth assessment, $R i$ cinodendron heudelotii (Baill.) Pierre ex Pax planted at a $6 \mathrm{~m}$ alley width had better growth than those in a $3 \mathrm{~m}$ alley in terms of height, collar diameter and number of leaves (Table 1). The statistics show that the effect of alley width was significant $(p<0.05)$ on the height, collar diameter and the number of leaves produced by the trees (Table 1 ).

The growth characteristics of Ricinodendron heudelotii observed in this study is a good indication that it has the potential for agroforestry purpose. One of the most important qualities of a good agroforestry tree is the fast growth rate, which has been undoubtedly demonstrated by the one-year early growth of this tree species. The average height of $R$. heudelotii recorded in this study superseded the average height of 4-year old Gmelina arborea that was reported by Aleksandrowicz-Trzcinska et al. (2017). Over the years, it has been mentioned and believed that exotic tree species grow faster than the indigenous tree species of which one of the exotic tree species with the so-

Table 1. Growth characteristics of a year old Ricinodendron heudelotii

\begin{tabular}{|c|c|c|c|c|}
\hline Alley width & Height $\pm \mathrm{SD}, \mathrm{mm}$ & Collar diameter $\pm \mathrm{SD}, \mathrm{mm}$ & Number of leaves & $\begin{array}{c}\text { Mann-Whitney } \mathrm{U} \\
\text { value }\end{array}$ \\
\hline $3 \mathrm{~m}$ & $1705.0 \pm 73.6$ & $201.2 \pm 12.1$ & 24 & 262.500 \\
\hline $6 \mathrm{~m}$ & $2557.1 \pm 66.5$ & $381.0 \pm 12.0$ & 31 & \\
\hline$t$-value & 4.972 & 6.054 & & \\
\hline $\mathrm{df}$ & 66 & 66 & & \\
\hline$p$-value & $0.000^{*}$ & $0.000^{*}$ & $0.000^{*}$ & \\
\hline
\end{tabular}

* = significant at $5 \%$ probability level.

$\mathrm{SD}=$ standard deviation. 
called fast growth rate happened to be G. arborea, but this was recently disproved by Onefeli, Adesoye (2014), with on-site pragmatic study by comparing the exotic species growth with the indigenous species. These authors concluded that some of our indigenous tree species grow faster than the exotic species. Although this study may not have been conducted under the same environmental condition with that of Aleksandrowicz-Trzcinska et al. (2017), the present finding and the previous report (Onefeli, Adesoye, 2014) have further strengthened the fact that some indigenous tree species like $R$. heudelotii possess a faster growth rate than the exotic counterpart.

The results (Table 2 ) show that the average height of maize in the $6 \mathrm{~m}$ alley, $3 \mathrm{~m}$ alley and control were 1187.0, 1051.2 and $743.1 \mathrm{~mm}$, respectively. The average collar diameter of maize in the $6 \mathrm{~m}$ alley was $121.4 \mathrm{~mm}$, for the $3 \mathrm{~m}$ alley it was $124.3 \mathrm{~mm}$ while the control maize had an average collar diameter of $97.1 \mathrm{~mm}$. Maize in both alley widths had the same number of leaves of 7 while the control maize had 6 . The statistics show that the effect of alley treatments on maize growth characteristics was significant $(p<0.05)$. The significant effect of alley widths on the maize growth characteristics observed in this study is in agreement with the study by Reyn- olds et al. (2007). However, the average height of maize for the present study is higher than what was reported by Reynolds et al. (2007) and this may be due to the differences in the study site, maintenance practices utilized and maize variety. The better performance of maize grown in between alleys than the control plot can be linked to the fact that the $R$. heudelotii used as the alleys contributed significantly to the nutrients utilized by the maize. This finding, however, contradicted the report of Elton (2013), which indicated that maize sown in an open field had better growth and yield compared to the maize intercropped with trees. This difference may be due to the fact that the growth of some trees retards the growth of other plants that are found around them through allelopathic inhibition (Aleem et al., 2014).

The effect of maize planting distance on the trees was not significant $(p>0.05)$ on the maize growth characteristics (Table 3 ). However, maize sown at $300 \mathrm{~cm}$ to the trees was the highest $(1098.4 \mathrm{~mm})$. This was closely followed by those sown at 240,180 and $120 \mathrm{~cm}$ to the trees with an average height of 1033.1, 1031.0 and $906.2 \mathrm{~mm}$, respectively. Maize sown at 300 and $120 \mathrm{~cm}$ to the trees had an equal number of leaves, which was 7 , while those that were at 180 and $240 \mathrm{~cm}$ produced 8 leaves each.

Table 2. Growth characteristics of maize grown within different alley widths

\begin{tabular}{ccc|c}
\hline Treatments & Height, $\mathbf{m m}$ & Collar diameter, $\mathbf{m m}$ & Number of leaves \\
\hline $6 \mathrm{~m}$ & $1187.0 \pm 13.8 \mathrm{a}$ & $121.4 \pm 4.0 \mathrm{ab}$ & 7 \\
\hline $3 \mathrm{~m}$ & $1051.2 \pm 29.2 \mathrm{a}$ & $124.3 \pm 3.2 \mathrm{a}$ & 7 \\
\hline Control & $743.1 \pm 19.1 \mathrm{~b}$ & $97.1 \pm 3.1 \mathrm{~b}$ & 6 \\
\hline$p$-value & $0.015^{*}$ & $0.000^{*}$ & $0.006^{*}$ \\
\hline
\end{tabular}

* = significant at $5 \%$ probability level.

$\mathrm{SD}=$ standard deviation.

Note. Means with a similar alphabet along the same column are not significantly different.

Table 3. Growth characteristics of maize with different planting distance to the tree

\begin{tabular}{cccc}
\hline Distance to the tree & Height, $\mathbf{~ m m}$ & Collar diameter, $\mathbf{m m}$ & Number of leaves \\
\hline $120 \mathrm{~cm}$ & $906.2 \pm 26.5$ & $111.0 \pm 3.1$ & 7 \\
\hline $180 \mathrm{~cm}$ & $1031.0 \pm 29.2$ & $125.4 \pm 3.2$ & 8 \\
\hline $240 \mathrm{~cm}$ & $1033.1 \pm 32.5$ & $122.0 \pm 3.2$ & 8 \\
\hline $300 \mathrm{~cm}$ & $1098.4 \pm 30.8$ & $124.1 \pm 4.1$ & 7 \\
\hline$p$-value & $0.153 \mathrm{~ns}$ & $0.399 \mathrm{~ns}$ & $0.102 \mathrm{~ns}$ \\
\hline
\end{tabular}

ns $=$ not significant at $5 \%$ probability level.

$\mathrm{SD}=$ standard deviation. 
Although the distance of maize to the tree did not significantly influence the growth characteristics of maize, maize that were farther to the trees performed better than the maize located very close to the alleys. This implies that the shade created by the branches of the trees may have interrupted the amount of light that reaches the maize.

The average coppiced length of $R$. heudelotii in the $3 \mathrm{~m}$ alley $(672.3 \mathrm{~mm})$ was insignificantly $(p>0.05)$ higher than that of the $6 \mathrm{~m}$ alley $(645.1 \mathrm{~mm})$ after three months (Fig. 1). A significant $(p<0.05)$ difference was observed between the number of leaves produced by $3 \mathrm{~m}$ alley trees (15) and $6 \mathrm{~m}$ alley trees (20) (Fig. 2). Tree species with the ability to withstand repeated pruning or pollarding with the pruned components, also be- ing useful for other purposes such as a folder for animals or as mulch for soil fertility enhancer, were categorized as a unique candidate for agroforestry tree by Tengnas (1994). The average coppiced height recorded in this study has given a clear fact that $R$. heudelotii possesses such attributes. The significant higher quantity of leaves produced by the $6 \mathrm{~m}$ alleys than those of the $3 \mathrm{~m}$ alleys may be ascribed to the wider row planting distance between the trees in the $6 \mathrm{~m}$ alleys, which would have necessitated the production of many branches that brought about the increased number of leaves. This agrees to the existing findings (Briggs et al., 2007; Glencross et al., 2012), which emphasised that aside genetic constitution, planting density and artificial pruning are the main measures regulating

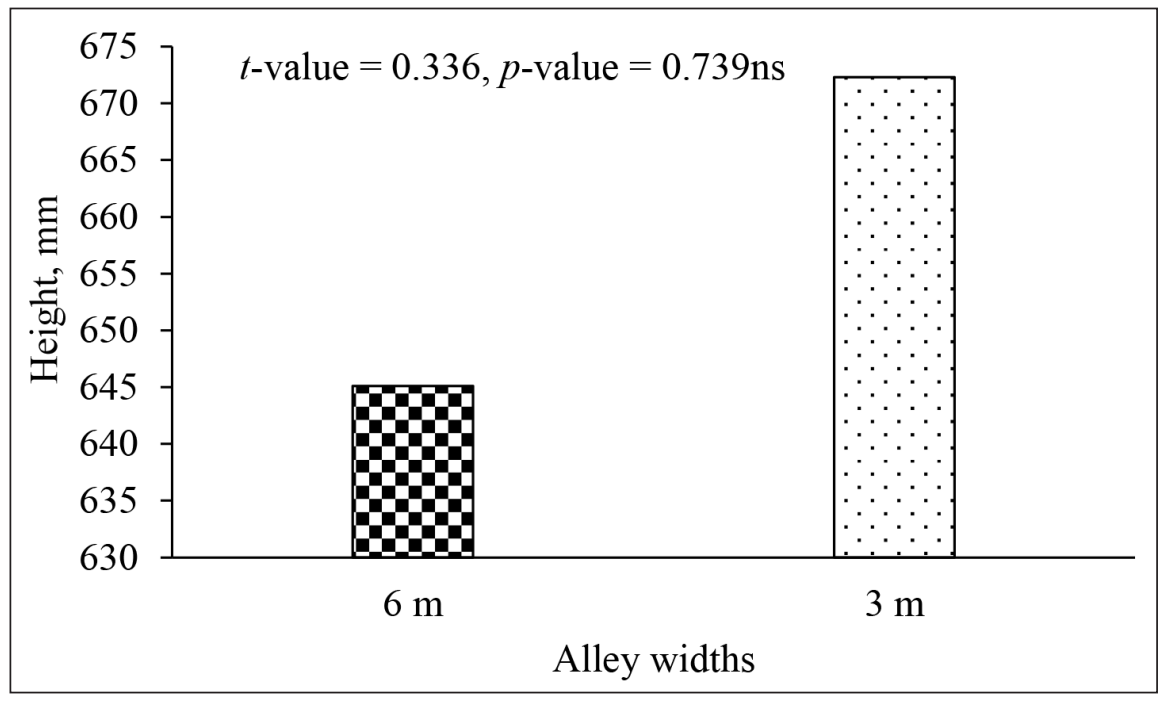

ns $=$ not significant at $5 \%$ probability level.

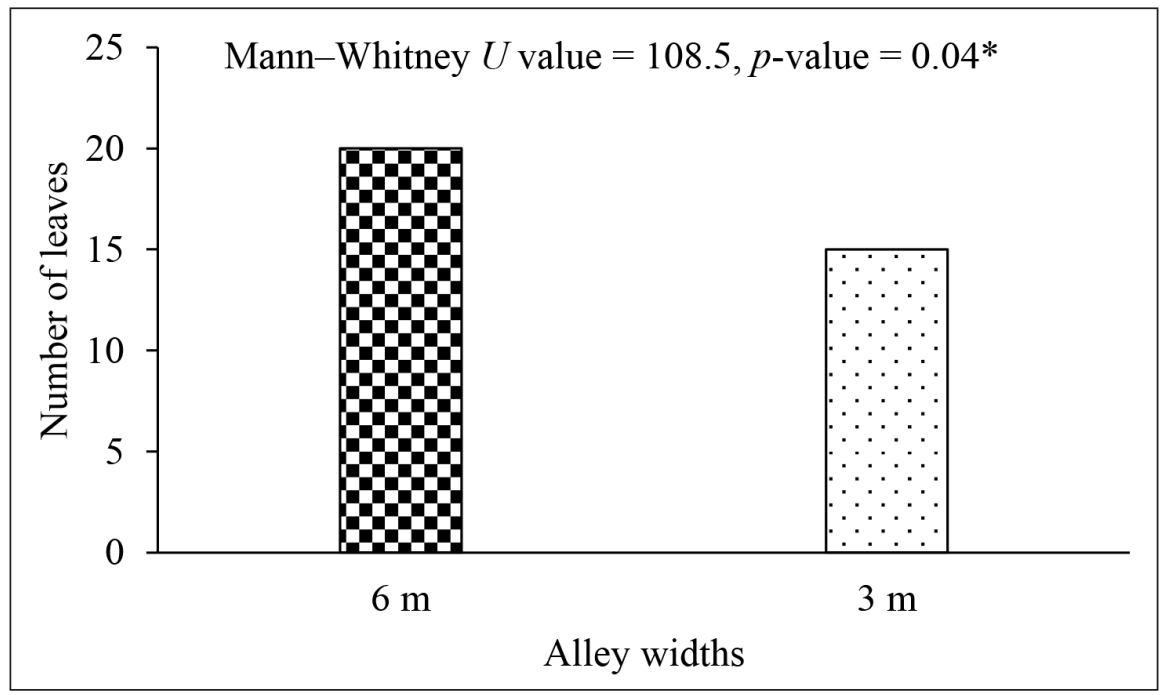

* = significant at $5 \%$ probability level.
Fig. 1. Length of Ricinodendron heudelotii coppices after three months of pollarding
Fig. 2. Number of leaves of Ricinodendron heudelotii coppices after three months of pollarding 
the branch development in trees. However, planting density may have no full control over the early formation of buds, but it does significantly influence the subsequent growth and persistent of branches that obstruct branch occlusion (Mäkinen, Hein, 2006; Hein et al., 2007; Wang et al., 2017).

Considering the soil properties of the agroforestry plot, organic carbon $(0.95 \%)$, nitrogen $(0.10 \%), \mathrm{pH}(6.14)$ and available phosphorus $\left(19.75 \mathrm{mg} \mathrm{kg}^{-1}\right.$ ) before the experiment were lower compared to $1.23 \%, 0.13 \%, 6.36$ and $23.91 \mathrm{mg} / \mathrm{kg}$, respectively, after the experiment (Table 4). Pre-experiment exchangeable cations/bases (Ca 0.95, Mg 0.41, K 0.85 and $\mathrm{Na} 0.34 \mathrm{cmol} \mathrm{kg}^{-1}$ ) were also lower when compared with the post-experiment $(\mathrm{Ca} 1.27$,
$\mathrm{Mg} 0.49, \mathrm{~K} 0.88$ and $\left.\mathrm{Na} 0.39 \mathrm{cmol} \mathrm{kg}^{-1}\right)$. Likewise, the iron $(\mathrm{Fe})$ concentration of the soil was higher in the post-experimental period $\left(187.44 \mathrm{mg} \mathrm{kg}^{-1}\right)$ than in the pre-experimental period $\left(131.80 \mathrm{mg} \mathrm{kg}^{-1}\right)$. The $t$-test result (Table 4) shows that the impact of the agroforestry on the soil $\mathrm{pH}$, available phosphorus, magnesium and sodium was significant $(p<0.05)$, while the agroforestry effect was not significant $(p>0.05)$ on carbon, nitrogen, calcium, potassium and iron. The effect of the agroforestry treatments was significant $(p<0.05)$ on all the analysed soil properties except for organic carbon, nitrogen and micronutrient Fe (Table 5) with the control plot having the least values. The highest values were estimated in the $3 \mathrm{~m}$

Table 4. Nutrient composition of the soil before and after the agroforestry experiment, Ricinodendron heudelotii

\begin{tabular}{|c|c|c|c|c|c|c|c|c|c|}
\hline $\begin{array}{l}\text { Ana- } \\
\text { lysis } \\
\text { period }\end{array}$ & $\mathrm{pH} \pm \mathrm{SD}$ & $\begin{array}{c}\mathrm{C} \pm \mathrm{SD} \\
\%\end{array}$ & $\begin{array}{c}\mathrm{N} \pm \mathrm{SD} \\
\%\end{array}$ & $\begin{array}{l}\mathrm{P} \pm \mathrm{SD} \\
\mathrm{mg} \mathrm{kg}^{-1}\end{array}$ & $\begin{array}{c}\mathrm{Ca} \pm \mathrm{SD} \\
\mathrm{cmol} \\
\mathrm{kg}^{-1}\end{array}$ & $\begin{array}{l}\mathrm{Mg} \pm \mathrm{SD} \\
\mathrm{cmol} \mathrm{kg}^{-1}\end{array}$ & $\begin{array}{c}\mathrm{K} \pm \mathrm{SD} \\
\mathrm{cmol} \\
\mathrm{kg}^{-1}\end{array}$ & $\begin{array}{l}\mathrm{Na} \pm \mathrm{SD} \\
\mathrm{cmol} \mathrm{kg}^{-1}\end{array}$ & $\begin{array}{c}\mathrm{Fe} \pm \mathrm{SD} \\
\mathrm{mg} \mathrm{kg}^{-1}\end{array}$ \\
\hline $\begin{array}{c}\text { Before } \\
\text { experi- } \\
\text { ment }\end{array}$ & $\begin{array}{c}6.14 \pm \\
0.25\end{array}$ & $\begin{array}{c}0.95 \pm \\
0.30\end{array}$ & $\begin{array}{c}0.10 \pm \\
0.02\end{array}$ & $\begin{array}{c}19.75 \pm \\
5.25\end{array}$ & $\begin{array}{c}0.95 \pm \\
0.24\end{array}$ & $\begin{array}{c}0.41 \pm \\
0.05\end{array}$ & $\begin{array}{c}0.85 \pm \\
0.09\end{array}$ & $\begin{array}{c}0.34 \pm \\
0.05\end{array}$ & $\begin{array}{c}131.80 \pm \\
18.9\end{array}$ \\
\hline $\begin{array}{l}\text { After } \\
\text { experi- } \\
\text { ment }\end{array}$ & $\begin{array}{c}6.36 \pm \\
0.16\end{array}$ & $\begin{array}{c}1.23 \pm \\
0.47\end{array}$ & $\begin{array}{c}0.13 \pm \\
0.05\end{array}$ & $\begin{array}{c}23.91 \pm \\
1.98\end{array}$ & $\begin{array}{c}1.27 \pm \\
0.37\end{array}$ & $\begin{array}{c}0.49 \pm \\
0.08\end{array}$ & $\begin{array}{c}0.88 \pm \\
0.06\end{array}$ & $\begin{array}{c}0.39 \pm \\
0.01\end{array}$ & $\begin{array}{c}187.44 \pm \\
57.6\end{array}$ \\
\hline$p$-value & $0.013^{\star}$ & $0.230 \mathrm{~ns}$ & $0.209 \mathrm{~ns}$ & $0.014^{*}$ & $0.098 \mathrm{~ns}$ & $0.039^{*}$ & $0.362 \mathrm{~ns}$ & $0.006^{*}$ & $0.050 \mathrm{~ns}$ \\
\hline
\end{tabular}

* = significant at $5 \%$ probability level.

ns $=$ not significant at $5 \%$ probability level.

$\mathrm{SD}=$ standard deviation.

Table 5. Soil nutrient composition of the different treatments

\begin{tabular}{|c|c|c|c|c|c|c|c|c|c|}
\hline $\begin{array}{l}\text { Treat- } \\
\text { ments }\end{array}$ & $\begin{array}{c}\mathrm{pH} \pm \\
\mathrm{SD}\end{array}$ & $\begin{array}{c}\mathrm{O} . \mathrm{C} \pm \mathrm{SD} \\
\%\end{array}$ & $\begin{array}{c}\mathrm{N} \pm \mathrm{SD} \\
\%\end{array}$ & $\begin{array}{l}\mathrm{P} \pm \mathrm{SD} \\
\mathrm{mg} \mathrm{kg}^{-1}\end{array}$ & $\begin{array}{c}\mathrm{Ca} \pm \mathrm{SD} \\
\mathrm{cmol}^{-} \\
\mathrm{kg}^{-1}\end{array}$ & $\begin{array}{c}\mathrm{Mg} \pm \mathrm{SD} \\
\mathrm{cmol} \\
\mathrm{kg}^{-1}\end{array}$ & $\begin{array}{c}\mathrm{K} \pm \mathrm{SD} \\
\mathrm{cmol} \\
\mathrm{kg}^{-1}\end{array}$ & $\begin{array}{l}\mathrm{Na} \pm \mathrm{SD} \\
\mathrm{cmol} \mathrm{kg}^{-1}\end{array}$ & $\begin{array}{c}\mathrm{Fe} \pm \mathrm{SD} \\
\mathrm{mg} \mathrm{kg}^{-1}\end{array}$ \\
\hline $3 \mathrm{~m}$ & $\begin{array}{c}6.35 \pm \\
0.18 \mathrm{a} \\
\end{array}$ & $\begin{array}{c}1.27 \pm \\
0.46\end{array}$ & $\begin{array}{c}0.14 \pm \\
0.05\end{array}$ & $\begin{array}{c}23.39 \pm \\
1.23 a\end{array}$ & $\begin{array}{c}1.26 \pm \\
0.38 \mathrm{a}\end{array}$ & $\begin{array}{c}0.51 \pm \\
0.08 \mathrm{a}\end{array}$ & $\begin{array}{c}0.88 \pm \\
0.06 \mathrm{a}\end{array}$ & $\begin{array}{c}0.38 \pm \\
0.01 \mathrm{a} \\
\end{array}$ & $\begin{array}{c}174.25 \pm \\
40.11\end{array}$ \\
\hline $6 \mathrm{~m}$ & $\begin{array}{c}6.34 \pm \\
0.12 \mathrm{a} \\
\end{array}$ & $1.11 \pm 0.43$ & $\begin{array}{c}0.12 \pm \\
0.04 \\
\end{array}$ & $\begin{array}{c}24.61 \pm \\
2.69 \mathrm{a} \\
\end{array}$ & $\begin{array}{c}1.22 \pm \\
0.31 \mathrm{a} \\
\end{array}$ & $\begin{array}{l}0.45 \pm \\
0.03 \mathrm{ab}\end{array}$ & $\begin{array}{c}0.89 \pm \\
0.07 \mathrm{a} \\
\end{array}$ & $\begin{array}{c}0.39 \pm \\
0.01 \mathrm{a} \\
\end{array}$ & $\begin{array}{c}191.29 \pm \\
77.54\end{array}$ \\
\hline Control & $\begin{array}{c}6.00 \pm \\
0.00 \mathrm{~b}\end{array}$ & $0.70 \pm 0.00$ & $\begin{array}{c}0.08 \pm \\
0.00\end{array}$ & $\begin{array}{l}14.2 \pm \\
0.00 \mathrm{~b}\end{array}$ & $\begin{array}{l}0.71 \pm \\
0.00 \mathrm{~b}\end{array}$ & $\begin{array}{c}0.35 \pm \\
0.00 \mathrm{~b}\end{array}$ & $\begin{array}{l}0.76 \pm \\
0.00 \mathrm{~b}\end{array}$ & $\begin{array}{c}0.29 \pm \\
0.00 \mathrm{~b}\end{array}$ & $\begin{array}{c}114.00 \pm \\
0.00\end{array}$ \\
\hline$p$-value & $0.036^{*}$ & $0.236 \mathrm{~ns}$ & $0.220 \mathrm{~ns}$ & $0.000^{*}$ & $0.044^{*}$ & $0.015^{\star}$ & $0.044^{*}$ & $0.000^{*}$ & $0.238 \mathrm{~ns}$ \\
\hline
\end{tabular}

* $=$ significant at $5 \%$ probability level.

O.C = organic carbon.

$\mathrm{SD}=$ standard deviation.

ns $=$ not significant at $5 \%$ probability level.

Note. Means with a similar alphabet along the same column are not significantly different. 
alley width for $\mathrm{pH}(6.35)$, organic carbon $(1.27 \%)$, nitrogen $(0.14 \%)$, calcium $(1.26 \mathrm{cmol}$ $\left.\mathrm{kg}^{-1}\right)$ and magnesium $\left(0.51 \mathrm{cmol} \mathrm{kg}^{-1}\right)$. Whereas the $6 \mathrm{~m}$ alley width had the highest value for phosphorus (24.61 mg kg-1), potassium $\left(0.89 \mathrm{cmol} \mathrm{kg}^{-1}\right)$, natrium $\left(0.39 \mathrm{cmol} \mathrm{kg}^{-1}\right)$ and iron $\left(191.29 \mathrm{mg} \mathrm{kg}^{-1}\right)$.

The positive impact of this agroforestry trial on the soil properties disagrees with Anikwe et al. (2015) in which drastic depletion of soil nutrients was reported in the post-experiment soil analysis result. This improvement in soil nutrients of the agroforestry plot after the trial may be ascribed to the pruning materials that were utilized as mulch on the soil. There are replete of findings (Jodaugienè et al., 2006; Kar, Kumar, 2007; Singh et al., 2007; Sinkevičienè et al., 2009), where the application of organic mulch improved the properties of depleted soil, which indirectly increased crop yields. According to Sinkevičienè et al. (2009), the use of organic mulches as a soil cover is efficiently effective in improving the quality of soil and increasing crop yield, especially in organic farming. Hence, the notable coppicing property of $R$. heudelotii vis-à-vis its ability to withstand pruning put it at a great advantage for agroforestry purpose.

\section{CONCLUSIONS}

This study has shown that Ricinodendron heudelotii (Baill.) Pierre ex Pax, being a non-leguminous multipurpose tree, has the potential for agroforestry purpose. This emanated from the fact that the tree is a fast-growing species, which attained the height and collar diameter of about 2557 and $381 \mathrm{~mm}$, respectively, in one year. This growth rate is higher than what has been reported for Gmelina arborea that is one of the fastest-growing exotic tree species in Nigeria. Hence, this finding has disapproved the fact that exotic trees grow faster than the indigenous trees in Nigeria, however, there is a need for repetition of the study in different parts of the country for further confirmation. It was discovered that this agroforestry practice improved the nutrient qualities of the soil. This study revealed that the maize plant can be intercropped with the alleys of Ricinodendron heudelotii (Baill.) Pierre ex Pax to achieve a complimentary and better output than the monoculture system of only crop or tree with some precautions. On the aver- age, a $6 \mathrm{~m}$ alley can be preferred as a better width for the selected tree species and maize crop. Therefore, agroforestry systems have the capacity to promote the transition to multifunctional agriculture that successfully ameliorates the problems of increasing the products of the crop in tandem with the provision of other ecosystem services.

\section{ACKNOWLEDGEMENTS}

The authors specially appreciate the Director of the Teaching and Research Farm, University of Ibadan, for providing the space for this agroforestry study.

Received 4 March 2019 Accepted 30 September 2019

\section{REFERENCES}

1. Akinbisoye O. S., Oke S. O., Adebola S. I., Mokwenye A. I. 2014. Influence of Taungya agroforestry system on diversity of native woody species and soil physico-chemical properties in Nigeria. International Journal of Scientific and Research Publications. Vol. 4. No. 3. P. 1-15.

2. Aleem M. O., Alamu L. O., Olabode O. S. 2014. Allelopathic effects of some selected tree species on the germination and growth of cowpea (Vigna unguiculata L. Walp.). Open Journal of Forestry. Vol. 4. P. 310-315.

3. Aleksandrowicz-Trzcinska M., Drozdowski S., Studnicki M., Zybura H. 2017. Effects of site preparation methods on the establishment and naturalregeneration traits of scots pines (Pinus sylvestris L.) in Northeastern Poland. Forest. Vol. 8. P. 1-17.

4. Amujoyegbe B. J., Elemo K. A. 2011. Decline in crop productivity in Nigeria: a review of possible strategies for self-reliance, increase and sustained production. Journal of Agriculture and Biological Sciences. Vol. 3. No. 1. P. 250-256.

5. Anigbogu N. M. 1996. Nature's gifts: improving trees and shrubs around the world. Ricinodendron heudelotii in Nigeria. Agroforestry Today. Vol. 8. P. 18.

6. Anikwe M. A. N., Emmanuel O. P., Eze J. C., Ibudialo A. N., Edeh V. N. 2015. Identifying fertilizer management strategies to maximize soil nutrient acquisition by cocoyam (Colocasia esculenta) in a degraded Ultisol in Agbani, Enugu Area, Southeastern Nigeria. American Journal of Plant Nutrition and Fertilization Technology. Vol. 5. No. 2. P. 61-70.

7. Barrios E., Sileshi G. W., Shepherd K., Sinclair F. 2019. Agroforestry and Soil Health: Linking Trees, Soil Biota, and Ecosystem Services. 16 p. [cited 
28.02.2019]. Available at: https://www.worldagroforestry.org/downloads/Publications/PDFS/ BC12072.pdf

8. Briggs D., Ingaramo L., Turnblom E. 2007. Number and diameter of breast-height region branches in a Douglas-fir spacing trial and linkage to log quality. Forest Products Journal. Vol. 57. P. 28-34.

9. Cosyns H., Van-Damme P., De-Wulf R., Degrande A. 2014. Can rural development projects generate social capital? A case study of Ricinodendron heudelotii kernel marketing in Cameroon. Small-scale Forestry. Vol. 13. No. 2. P. 163-182.

10. Elton N. 2013. Impact of Tree Species on Maize Productivity by Smallholder Farmers in Eastern Kenya. A Dissertation submitted to the Faculty of Agriculture in partial fulfilment of the requirements of MSc in Research Methods degree at Jomo Kenyatta University of Agriculture and Technology. $114 \mathrm{p}$.

11. Facheux C., Gyau A., Russell D., FoundjemTita D., Mbosso C., Franzel S., Tchoundjeu Z. 2012. Comparison of three modes of increasing benefits to farmers within agroforestry tree products market chains in Cameroon. African Journal of Agricultural Research. Vol. 7. P. 2336-2343.

12. Falade O. F., Bada S. O. 2009. Early growth and dry matter yield of Gmelina arborea (roxb) on basement complex and Ferric Luvisol soils. Nigerian Journal of Forestry. Vol. 39. No. 1. P. 15-21.

13. FAO. 2012. Enhancing the Contribution of Nonwood Forest Products to Poverty Alleviation and Food Security in Central African Countries. Information Note. No. 8. 2 p.

14. Fuashi N. A., Popoola L., Joseph E., Wehmbazeyi N. F., Louis N. N., Ela E. M. 2011. Gathering processing and marketing of Ricinodendron species (Bail) in the humid forest zone of Cameroon. Agricultural Science Resources Journal. Vol. 1. No. 9. P. 213-221.

15. Glencross K., Nichols J. D., Grant J. C., Sethy M., Smith R. G. B. 2012. Spacing affects stem form, early growth and branching in young whitewood (Endospermum medullosum) plantations in Vanuatu. International Forestry Review. Vol. 14. P. 442-451.

16. Hein S., Mäkinen H., Yue C., Kohnle U. 2007. Modelling branch characteristics of Norway spruce from wide spacings in Germany. Forest Ecology and Management. Vol. 242. P. 155-164.

17. Jodaugienè D., Pupalienè R., Urbonienė M., Pranckietis V., Pranckietiene I. 2006. The impact of different types of organic mulches on weed emergence. Agronomy Research. Vol. 4. P. 197-200.

18. Kar G., Kumar A. 2007. Effects of irrigation and straw mulch on water use and tuber yield of potato in eastern India. Agricultural Water Management. Vol. 94. P. 109-116.
19. Keerthisena R. S. K., Gunawardana G. 1996. Effect of cutting height and alley width on biomass production of Leucaena leucocephala in an alley cropping system. Forest, Farm, and Community Tree Research Reports. Vol. 1. P. 90-92.

20. Krasauskas A. 2018. Fungi isolated from maize (Zea mays L.) grain in Lithuania. Agricultural Sciences. Vol. 25. No. 4. P. 169-176.

21. Mäkinen H., Hein S. 2006. Effect of wide spacing on increment and branch properties of young Norway spruce. European Journal of Forest Research. Vol. 125. P. 239-248.

22. Mukul S. A., Herbohn J. 2016. The impacts of shifting cultivation on secondary forests dynamics in tropics: A synthesis of the key findings and spatio temporal distribution. Environmental Science \& Policy. Vol. 55. P. 167-177.

23. Ndumbe L. N., Ingram V., Tchamba M., Nya S. 2018. From trees to money: The contribution of Njansang (Ricinodendron heudelotii) products to value chain stakeholders' financial assets in the South West Region of Cameroon. Forests, Trees and Livelihoods. P. 1-16.

24. Ngo-Mpeck M. L., Asaah E., Tchoundjeu Z., Atangana A. R. 2003. Strategies for the domestication of Ricinodendron heudelotii: Evaluation of variability in natural populations from Cameroon. Food Agriculture and Environment. Vol. 1. No. 3. P. 257-262.

25. Nzali H. G., Tchiegang C., Sandjon B., Meurens M. 2016. Comparison of some physicochemical properties of oil extracted from Ricinodendron heudelotii (Bail.) kernels by UV spectrophotometer. International Journal of Biosciences. Vol. 8. No. 6. P. 93-102.

26. Oke D. O., Odebiyi K. A. 2007. Traditional cocoabased agroforestry and forest species conservation in Ondo State, Nigeria. Agriculture, Ecosystems and Environment. Vol. 122. P. 305-311.

27. Onefeli A. O., Adesoye P. O. 2014. Early growth assessment of selected exotic and indigenous tree species in Nigeria. South-east European Forestry. Vol. 5. No. 1. P. 45-51.

28. Plenderleith K. 2004. Njansang (Ricinodendron heudelotii subsp. Africanum). In: The Key Nontimber Forest Products of Central Africa: State of the Knowledge. Technical Paper. No. 122. Washington DC, USA: USAID. P. 63-86.

29. Reynolds P. E., Simpson J. A., Thevathasan N. V., Gordon A. M. 2007. Effects of tree competition on corn and soybean photosynthesis, growth, and yield in a temperate tree-based agroforestry intercropping system in Southern Ontario, Canada. Ecological Engineering. Vol. 29. P. 362-371.

30. Singh R. S., Sharma R. R., Goyal R. K. 2007. Interacting effects of planting time and mulching on 'Chandeler' strawberry (Fragaria $\times$ ananassa Duch.). Scientia Horticulturae. Vol. 111. P. 344-351. 
31. Sinkevičienė A., Jodaugienė D., Pupalienė R., Urbonienè M. 2009. The influence of organic mulches on soil properties and crop yield. Agronomy Research. Vol. 7. No. 1. P. 485-491.

32. Tchoundjeu Z., Atangana A. R. 2006. Ricinodendron heudelotii. Southampton, UK: Southampton Centre for Underutilised Crops, University of Southampton. $85 \mathrm{p}$.

33. Tengnas B. 1994. Agroforestry Extension Manual for Kenya. Nairobi: International Centre for Research in Agroforestry. 188 p.

34. Tiki-Manga T., Fondoun J. M., Kengue J., Tchiegang C. 2000. Chemical composition of Ricinodendron heudelotii: An indigenous fruit tree in southern Cameroon. African Crop Science Journal. Vol. 8. P. 195-201.

35. Udo I. O., Epidi T. T. 2009. Biological effect of ethanolic extract fractions of Ricinodendron heudelotii (Baill) Pierre ex Pax against Sitophilus zeamais Motschulsky and Callosobruchus maculates Fabricius on stored grains. African Journal of Agricultural Research. Vol. 4. No. 10. P. 1080-1085.

36. Verinumbe I. 2017. Evaluation of tree species for agroforestry practice on Entisols in the Sudan Sahel Region of Nigeria. Environment and Ecology Research. Vol. 5. No. 2. P. 161-166.

37. Wang C. S., Zeng J., Hein S., Zhao Z. G., Guo J. J., Zeng J. 2017. Crown and branch attributes of midaged Betula alnoides plantations in response to planting density. Scandinavian Journal of Forest Research. Vol. 32. P. 679-687.

38. Yirankinyuki F. F., Lamayi D. W., Muhammad U. A., Musa B. 2018. Assessing the suitability of Ricinodendron heudelotii seed oil for paint formulation. IOSR Journal of Applied Chemistry. Vol. 11. No. 7. P. 37-42.

39. Zerotabou 2019. Ricinodendron heudelotii: Its Properties and Uses [cited 26.02.2019]. Available at: https://zerotabou.agoraafricaine.info/2019/01/22/ le-ricinodendron-heudelotii-ses-proprietes-etutilisations

\section{Alfred Ossai Onefeli, Adejoke Olukemi Akinyele, Hezekiah Tunde Fatoba \\ Ricinodendron heudelotii (Baill.) PIERRE EX PAX POTENCIALAS AGROMIŠKININKYSTEI NIGERIJOJE}

Santrauka

Dèl Nigerijos gyventojų skaičiaus didejjimo ir išeikvotų dirvožemio maistinių medžiagų šalyje sumažèjo žemės ūkio produkcijos. Tikslinga ịvertinti svarbius vietinius agromiškininkystès medžius, kurie tame pačiame žemès sklype derètų su žemès ūkio augalais. Šiame tyrime buvo siekiama nustatyti Ricinodendron heudelotii potencialą agromiškininkystei, daugiausia dèmesio skiriant medžio augimo tempui ex-situ, suderinamumui su kukurūzais, gebejjimu atželti ir jo poveikiui dirvožemio maistinėms medžiagoms.

Eksperimentas buvo įrengtas Ibadano universiteto Mokymo ir tyrimų ùkyje (Nigerija). Naudoti du alejos pločiai (3 ir $6 \mathrm{~m}$ ) ir kontrolè (15 ir $10 \mathrm{~m}$ ). Kukurūzai su medžiais buvo auginami sausuoju ir lietinguoju sezonais. Tyrimai atlikti praejus šešiems mėnesiams po medžių sodinimo, tolimesni tyrimai vykdyti su kukurūzais, kurie išliko tik lietingojo sezono metu. Surinkti duomenys apie medžių ir kukurūzų aukštị, stiebo skersmenį ir lapų skaičių. Dirvožemio analizès atliktos prieš ir po eksperimento. Duomenys buvo išanalizuoti statistiškai, atlikti ANOVA, t-testas, Kruskal Wallis ir MannWhitney $U$ testai.

Rezultatai parodè, kad alëjos pločio poveikis medžių ir kukurūzų augimui buvo esminis $(p<0,05)$, o $6 \mathrm{~m}$ alëja turèjo didžiausią poveikį. Sodinimo atstumo ịtaka kukurūzų augimui nebuvo reikšminga. Alëjos agromiškininkystès praktika iš esmès $(p<0,05)$ pagerino vietovès dirvožemio savybes, ypač $\mathrm{pH}$, fosforo, magnio ir natrio kiekius.

Šio tyrimo rezultatai parodè, kad kukurūzus galima ittraukti ị Ricinodendron heudelotii alejjos daugiafunkcini produktyvumą.

Raktažodžiai: agromiškininkystè, alèjos auginimas, Ricinodendron heudelotii, kukurūzai, dirvožemio maistinès medžiagos 